\title{
Surgical treatment of Zenker's diverticulum
}

Manejo quirúrgico del divertículo de Zenker

Enrique Rosales-Castañeda, Grecia C. García-Morán and José L. Martínez-Ordaz*

Department of Gastric Surgery, Specialty Hospital, Centro Médico Nacional Siglo XXI, Instituto Mexicano del Seguro Social, Mexico City, Mexico

\begin{abstract}
Background: Zenker's diverticulum represents the most common diverticulum of the esophagus. The standard surgical treatment consists of open cricopharyngeal myotomy with diverticulectomy. In recent years endoscopic treatment has been proposed. Objective: We present the surgical experience of this disease in a referral hospital. Method: We reviewed the clinical records of all patients submitted to open surgical treatment for Zenker's diverticulum in a 7-year period. The retrieved information included demographic data, clinical manifestations, diagnostic approach, surgery findings and postoperative evolution. Results: During this period 10 patients were submitted to open surgical treatment; the mean age was $64( \pm$ (8) years and seven of them were male. The main complaint was regurgitation and dysphagia that was present in eight and seven patients respectively. Diagnostic studies included endoscopy (nine patients), esophagogram (six patients) and esophageal manometry (three patients). All underwent open cricopharyngeal myotomy with diverticulectomy. Complications included intraoperative esophageal perforation (one patient) and postoperative esophageal fistula (one patient). Resolution of the symptomatology occurred in 9 patients, the other patient required a new myotomy six months later with good results. There was no mortality. Conclusions: Cricopharyngeal myotomy with diverticulectomy is a safe option for patients with Zenker's diverticulum.
\end{abstract}

KEY WORDS: Zenker's diverticulum. Pharyngoesophageal diverticulum. Pharyngoesophageal pulsion diverticula.

\section{Resumen}

Introducción: Los divertículos de Zenker son los divertículos más frecuentes del esófago. El tratamiento quirúrgico más utilizado es la diverticulectomía con miotomía del cricofaríngeo abierta. En años recientes se ha propuesto el tratamiento endoscópico. Objetivo: Presentar la experiencia en el manejo de esta patología en un hospital de referencia. Método: Fueron revisados los expedientes de los pacientes intervenidos quirúrgicamente por divertículo de Zenker en un periodo de 7 años. Los datos obtenidos incluyeron demográficos, cuadro clínico, abordaje diagnóstico, hallazgos transoperatorios y evolución posoperatoria. Resultados: Fueron intervenidos 10 pacientes durante este periodo, con una edad promedio de 64 años ( \pm 8); siete de ellos eran hombres. Los principales síntomas fueron regurgitación y disfagia, presentes en ocho y siete pacientes, respectivamente. Los estudios diagnósticos incluyeron endoscopia (nueve pacientes), esofagograma (seis pacientes) y manometría esofágica (tres pacientes). El tratamiento utilizado en todos los casos fue diverticulectomía con miotomía del cricofaríngeo. Las complicaciones incluyeron perforación esofágica transoperatoria (un paciente) y fístula esofágica (un paciente). Hubo resolución de los síntomas en nueve pacientes; el paciente restante ameritó nueva miotomía seis meses después, con una adecuada evolución. No hubo ninguna muerte. Conclusiones: La diverticulectomía con miotomía del cricofaríngeo es un tratamiento quirúrgico seguro para los pacientes con divertículo de Zenker.

PALABRAS CLAVE: Divertículo faringoesofágico. Divertículo de Zenker. Divertículo faringoesofágico por pulsión.

\author{
Correspondence: \\ *José Luis Martínez Ordaz \\ Av. Cuauhtémoc, $330,1^{\circ}$ \\ Col. Doctores, Del. Cuauhtémoc \\ C.P. 06725, Ciudad de México, México \\ E-mail: jlmo1968@ hotmail.com
}

Date of reception: 05-04-2018

Date of acceptance: 20-04-2018

DOI: 10.24875/CIRUE.M18000051
Cir Cir. 2018;86:314-317

Contents available at PubMed www.cirugiaycirujanos.com 


\section{Introduction}

Esophageal diverticula are uncommon, with a prevalence of 0.06 to $3.6 \%$ according to endoscopic or radiological series ${ }^{1-3}$.

The diverticula that most often occur are Zenker's diverticula, described by Abraham Ludlow 4 in 1769 and masterfully characterized by Friedrich Albert von Zenker ${ }^{5}$ one century later. They have a higher frequency in people older than 50 years, and are two to three times more common in the male gender ${ }^{6,7}$. Clinical presentation shows a great diversity, from scarce symptoms to patients with highly incapacitating symptomatology, which even can lead to a state of severe malnutrition.

The main therapeutic options are cricopharyngeal myotomy, diverticulopexy with cricopharyngeal myotomy and, the most widely used, diverticulectomy and cricopharyngeal myotomy ${ }^{8}$. The purpose of this study is to describe the surgical experience in a tertiary care hospital in the management of Zenker's diverticulum over a 7-year period.

\section{Method}

A retrospective review of all patients surgically treated in a tertiary care hospital for Zenker's diverticulum in the period encompassed from January 1, 2009 to December 31, 2015 was carried out. Once detected, demographic data (age, gender and comorbidity, among others), clinical presentation of the disease, preoperative studies performed related to the condition (barium esophagogram, endoscopy, and esophageal manometry), surgical treatment performed, postoperative complications and postoperative follow-up were inspected.

Owing to the number of patients that were found, the review was carried out as a statistical analysis, with central tendency and dispersion measures being used for continuous variables, and for nominal variables, frequencies, ratios and proportions were determined (the percentage was omitted, since the sample was composed of 10 patients).

\section{Results}

During the study period, 10 patients were reported to have been surgically intervened for Zenker's diverticulum. Mean age was $64( \pm 8)$ years. Seven subjects were males and three were females. Most common

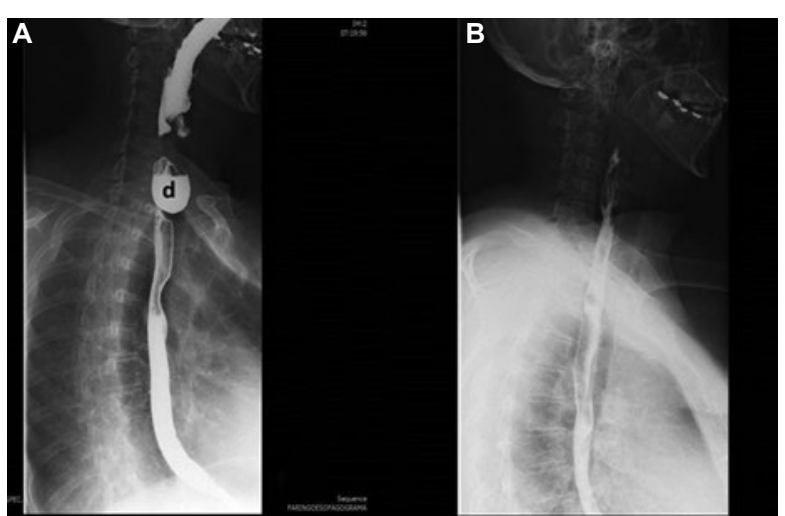

Figure 1. A: barium esophagogram, where the image of a Zenker diverticulum (d) is observed. B: postoperative barium esophagogram after cricopharyngeal myotomy and diverticulectomy.

comorbidity was hypertension in four patients, followed by diabetes mellitus in three. One patient had a history of endoscopic management of a diverticulum with transoral stapler.

The most common symptoms were regurgitation in eight patients, dysphagia in seven, halitosis in four and foreign body sensation in three. Four patients were previously classified as having symptoms consistent with gastroesophageal reflux. The Boyce sign (pushing the larynx laterally causes a gurgling sound) and Quinn's sign (regurgitation of food into the mouth by external compression of the pouch) were not found in our patients ${ }^{9}$.

Preoperative endoscopy was the most commonly used diagnostic study, in nine patients; barium esophagram was carried out in six, computed tomography in three and esophageal manometry in three.

All patients underwent diverticulectomy and cricopharyngeal myotomy through a left cervical incision. Diverticulectomy was carried out with stapler in all cases. Average trans-operative time was $99( \pm 19)$ minutes, and average trans-operative hemorrhage was $41( \pm 34) \mathrm{ml}$. Average diverticula size was 3.1 $( \pm 1) \mathrm{cm}$. During the trans-operative period, the only complication was an esophageal perforation (managed with primary closure and gastrostomy) (Fig. 1).

During postoperative evolution, one patient developed a low-output esophagocutaneous fistula, which was conservatively managed (parenteral nutrition and fasting), and the patient was discharged without complications. In nine patients, there was symptomatology resolution; the other patient had symptom recurrence and short cricopharyngeal myotomy was suspected, which required surgical re-intervention at 6 months, with a new cricopharyngeal myotomy being performed, 
which had an adequate postoperative evolution. There were no deaths recorded in this group of patients.

\section{Discussion}

The prevalence of esophageal diverticula in the general population is considered to range from 0.01 to $0.11 \%{ }^{10}$. Some publications refer a geographical distribution of this condition, although without specifying the causes, and highlight that it is quite rare in Japan and Indonesia, whereas in Northern Europe it is more common with regard to the south of this continent. In the USA, Canada and Australia it is usual and has a more homogeneous distribution. One study carried out in the United Kingdom estimated an annual incidence of 2 cases per 100,000 population ${ }^{11}$. In Mexico, there is not a concrete incidence report, and the few studies conducted refer a low incidence, as at Hospital General de Mexico, with an incidence of $0.04 \%$, after documenting three cases in five years ${ }^{12}$.

Zenker's diverticulum pathophysiology is not fully elucidated, but two theories are the most widely accepted: the one proposed by Westrin et al. ${ }^{13}$, who refer to the cause as weakness of the posterior pharyngeal wall muscles adjacent to the upper esophageal sphincter, and the one postulated by Jackson and Shallow ${ }^{14}$ attributes the formation of the diverticulum to cricopharyngeal muscle incoordination at the moment of swallowing.

The swallowing difficulty can be perceived by the patient as a mild, inconstant disorder that is linked to the type of ingestion during the first and second swallowing stages, known as oropharyngeal and pharyngeal swallowing, respectively, and as the size of the diverticulum increases, the swallowing difficulty becomes greater and constant. At an advanced state, the impossibility for the passage of the bolus has its origin in the compression exerted by the diverticular pouch onto the esophageal lumen.

Other symptoms are described, such as regurgitation, dyspnea due to micro-aspiration or due to compression of the airway when the diverticulum acquires a large size, halitosis and weight loss. In this study, regurgitation was the main symptom referred by the patients, followed by dysphagia and halitosis.

The most common complications are respiratory tract infections by aspiration of the diverticular content, perforation that can occur by endoscopy or by placement of an endotracheal tube, and others such as tracheoesophageal fistula, hemorrhage and paralysis of the vocal cords.
Possible malignant transformation of the diverticulum should be suspected in patients with worsening dysphagia, severe pain, episodes of hemoptysis and regurgitation increased intensity. The first author who described it was Schlesinger (cited by Halstead in 1903). It affects males with mean age of more than 50 years. In 1969, Wychulis described three cases in a series of 961 patients, with an incidence of $0.3 \%$. Hoover found two cases in a series of 185 patients, with an incidence of $1.1 \% \%^{9,12}$.

The study with contrast ingestion allows appreciating the shape, size and location of the diverticulum. Endoscopy has a controversial role, given that some authors claim that it is unnecessary and even risky, while others think it is complementary since it allows evaluating the possibility of structural changes in the diverticular mucosa. Esophageal manometry can demonstrate the association of the diverticulum with a cricopharyngeal muscle abnormal response to swallowing or even with hypertonia of said muscle. However, owing to the anatomy (very short sphincter) and physiology (sphincter movement during swallowing), assessment is rather complicated ${ }^{15}$.

Cricopharyngeal myotomy is the main component of surgical or endoscopic treatment. It should be carried out even without esophageal manometry results available ${ }^{16}$. Symptoms or diverticulum recurrence, and postoperative complications (e.g., fistula), are very frequently related to an incomplete myotomy. This was the treatment performed in all our patients. Diverticulectomy solves dysphagia-related symptoms better in comparison with myotomy alone and with diverticulopexy with myotomy ${ }^{16}$.

Endoscopic diverticulotomy is a technique described by Mosher ${ }^{17}$ in 1917, abandoned by the mediastinitis it produced, and resumed in 1951 by Dohl$\operatorname{man}^{16}$ with good results. It consists of dividing the septum between the cervical esophagus and the diverticular pouch. It can be performed with electrocautery, laser and, more recently, with a stapler. Its main advantage is short surgical time and quick return to the oral route. Currently, its use is not widespread. It had been practiced in one of our patients, with an unsatisfactory evolution.

Recurrence in patients with surgically-managed Zenker's diverticulum is $16 \%{ }^{18}$. As previously mentioned, completing the cricopharyngeal myotomy is usually sufficient for the treatment of diverticulum recurrence. Current mortality is $1-2 \%$. 


\section{Conclusions}

Zenker's diverticula are an infrequent diagnosis. There is little information in Mexico on their prevalence and on experience at high specialty medical care centers. Their symptomatology is usually vague. The diverticula reported in this study have a similar clinical presentation to those described in the international literature on clinical characteristics and diagnostic workup. The treatment used in all cases was diverticulectomy with cricopharyngeal myotomy, which currently is the most widely recommended approach.

\section{Ethical responsibilities}

Protection of people and animals. The authors declare that no experiments have been conducted on humans or animals for this research.

Confidentiality of data. The authors declare having followed the protocols of their work center on the publication of patient data.

Right to privacy and informed consent. The authors declare that no patient data appear in this article.

\section{Conflicts of interest}

The authors refer not having any conflict of interests relevant to this work.

\section{References}

1. Hoghooghi D, Coakley F V, Breiman RS, Qayyum A, Yeh BM. Frequency and etiology of midesophageal diverticula at barium esophagography. Clin Imaging. 2006;30:245-7.

2. Watanabe S, Matsuda K, Arima K, Uchida Y, Nishioka M, Haruo T, et al. Detection of subclinical disorders of the hypopharynx and larynx by gastrointestinal endoscopy. Endoscopy. 1996;28:295-8

3. Ekkberg O, Wahlgren L. Disfunction of pharyngeal swallowing. A cineradiographic investigation. Acta Radiol. 1985;26:389-95.

4. Ludlow A. A case of obstructed deglutition from a preternatural dilatation of, and bag formed in, the pharynx. Med Observ Enq. 1769;3:85-101.

5. Zenker FA, von Ziemssen H. Krankheiten des Oesophagus. En: von Ziemssen $\mathrm{H}$, editor. Handbuch der speciale Pathologie und Therapie. Leipzig, Germany: FC Vogel; 1877. p. 1-87.

6. Madick S. Perioperative care of the patient with Zenker's diverticulum. AORN J. 2001;73:904-13.

7. Onwugbufor MT, Obirieze AC, Ortega G, Allen D, Cornwell EE $3^{\text {rd }}$, Fullum TM. Surgical management of esophageal diverticulum: a review of the Nationwide Inpatient Sample database. J Surg Res. 2013;184:120-5.

8. Bonafede JP, Lavertu P, Wood BG, Eliacar I. Surgical outcome in 87 patients with Zenker's diverticulum. Laryngoscope. 1996;107:720-5.

9. Morales GD, Casanova RD, Garcia PM, Rodilla IG, Naranjo GA. Carcinoma epidermoide sobre un divertículo de Zenker. An Med Intern. 2002;19:27-30.

10. Watemberg S, Landau O, Avrahami R. Zenker's diverticulum: reappraisal. Am J Gastroenterol. 1996;91:1494-8.

11. Siddiq MA, Sood S, Strachan D. Pharyngeal pouch (Zenker's diverticulum). Postgrad Med J. 2001;77:506-11.

12. Pérez TE, Pérez PJ, Bernal SF, Abdo FJM, Murguía DD. Diagnóstico y tratamiento del divertículo de Zenker. Rev Med Hosp Gen Mex. 2005:68:155-9.

13. Westrin KM, Ergum S, Carsloo B. Zenker's diveticulum: a historical review and trends in therapy. Acta Otolaryngol (Stock). 1996;116:351-60.

14. Jackson C, Shallow TA. Diverticula of the esophagus: pulsion, traction, malignant and congenital. Ann Surg. 1926;83:1-19.

15. Sonbare DJ. Pulsion diverticulum of the oesophagus: more than just an out pouch. Indian J Surg. 2015;77:44-8.

16. Constantin A, Mates IN, Predescu D, Hoara P, Achim FI, Constantinoiu S Principles of surgical treatment of Zenker diverticulum. J Med Life. 2012;5:92-7.

17. Mosher $\mathrm{H}$. Webs and pouches of the oesophagus, their diagnosis and treatment. Surg Gynecol Obstet. 1917;25:175.

18. Skinner KA, Zuckerbraun L. Recurrent Zenker's diverticulum. Treatment with crycopharyngeal myotomy. Am Surg. 1998;64:192-4. 